\title{
Bioavailability of dissolved zinc to the common mussel Mytilus edulis in complexing environments
}

\author{
Kathleen Vercauteren*, Ronny Blust \\ Department of Biology, University of Antwerp (RUCA), Groenenborgerlaan 171, B-2020 Antwerp, Belgium
}

\begin{abstract}
The bioavailability of dissolved zinc to the common mussel Mytilus edulis was studied in chemically defined seawater containing 5 different organic ligands. Zinc uptake shows saturable kinetics, indicating that it is a facilitated process. The uptake of zinc from solution is nearly linear over a $24 \mathrm{~h}$. period for mussel tissues exposed to a $5 \mu \mathrm{mol} \mathrm{l}^{-1}$ concentration. In most cases, metal complexation decreases zinc uptake by reducing the activity of the free metal ion. Zinc uptake rates are similar for 4 of the 5 ligands studied when the free zinc ion activity is kept constant. Complexation of zinc with histidine facilitates the uptake of zinc. Whether the mechanism of facilitation involves the direct uptake of zinc-histidine complexes across the membrane cannot be deduced from the present study. For the same free zinc ion activity, the availability of zinc is higher in the digestive system than in the gills. The observed differences can be caused by changes in the chemical speciation of the metals in the layers lining the exchange surfaces where conditions may deviate considerably from seawater.
\end{abstract}

KEY WORDS: Mytilus edulis - Zinc speciation - Zinc uptake - Bioavailability

\section{INTRODUCTION}

In seawater dissolved trace metals occur in very low concentrations, ranging from 0.01 to $100 \mathrm{nmol} \mathrm{l}^{-1}$ (Ahrland 1985). Nonetheless they are accumulated by marine invertebrates to tissue concentrations much above the concentrations in the surrounding seawater. The extent of metal accumulation strongly depends on environmental conditions (Furness \& Rainbow 1990).

Certain metals such as iron, copper and zinc are essential to living organisms due to their role in metabolic processes. Zinc, for instance, serves as a cofactor for enzymes such as alcohol dehydrogenase, carbonic anhydrase and carboxypeptidase (Frausto Da Silva \& Williams 1991). All metals, essential or not, are toxic above certain threshold concentrations. The balance between the requirement and the toxicity of metals is delicate and depends on a variety of abiotic and biotic factors (White \& Rainbow 1985).

In marine environments metals occur as a variety of complexes with inorganic and organic ligands (Turner et al. 1981, Motekaitis \& Martell 1987, Bruland 1989).

•E-mail: katver@ruca.ua.ac.be
Turner et al. (1981) modelled the inorganic speciation of trace metals in seawater and showed that about half of the total zinc concentration exists as the free zinc ion, with the remaining zinc distributed among a series of inorganic species. Bruland (1989) demonstrated the existence of organic ligands in low nanomolar concentrations which form zinc complexes that strongly decrease the concentration of the free zinc ion.

The major factor controlling the uptake of metals by marine organisms is the bioavailability of the metal The biologically available fraction of a metal is that part of the total concentration in a form that can be taken up by an organism (Turner 1984). The bioavailability of metals to aquatic organisms strongly depends on the chemical speciation and it is generally accepted that the free metal ion is the most biologically available species (Zamuda \& Sunda 1982, Blust et al. 1992, Rainbow et al. 1993).

A widely accepted mechanism for metal uptake is the binding of the free metal ion to a membrane embedded channel type protein which mediates the transport of the metal ion across the membrane. The selectivity of these transporters depends on the size and charge of the channel, which could impede the 
transport of certain metal species (Simkiss \& Taylor 1989).

Mussels are widely used in marine pollution monitoring programs, because they (1) are geographically widely distributed, (2) have a sedentary lifestyle, (3) are filter feeders that pump large volumes of water and (4) accumulate pollutants, such as heavy metals, in their tissues (Phillips 1980, Widdows 1985, Farrington et al. 1987)

In the present work the effect of complexation by different water soluble ligands on the uptake of zinc by the common mussel Mytilus edulis has been studied in chemically defined seawater. The speciation of zinc was controlled by varying the concentration of 5 organic ligands. The ligands studied were citrate, glycine, histidine, NTA (nitrilotriacetic acid) and EDTA (ethylenedinitrilo-tetraacetic acid). These ligands were selected on the basis of differences in the thermodynamic stabiiity and charge of the formed zinc complexes which are representative of the wide variety of ligands in natural waters. Zinc uptake was studied in solutions of differing complexation capacity to reveal the role of the free metal ion and other species in determining the uptake of zinc in relation to the type and concentrations of the ligand present in the solution.

\section{MATERIALS AND METHODS}

Mytilus edulis. Mussels of approximately 6 to $8 \mathrm{~cm}$ in length were collected at low water sites at Westkapelle (The Netherlands) and were kept in a seawater aquarium containing 350 litres of synthetic seawater at a salimity of $35 \%$ ( $\mathrm{pH} 8.0$, temperature: $15 \pm 1^{\circ} \mathrm{C}$ ). The aquarium water was filtered over a trickling filter and tested weekly for $\mathrm{NH}_{4}{ }^{+}\left(<0.25 \mathrm{mg} \mathrm{l}{ }^{-1}\right), \mathrm{NO}_{2}{ }^{-}(<0.1 \mathrm{mg}$ $\mathrm{l}^{-1}$ ) and $\mathrm{NO}_{3}^{-}\left(<10 \mathrm{mg} \mathrm{l}^{-1}\right)$ (Hawkins 1981). The mussels were fed with a mixture of dried Spirulina platensis and Saccharomyces cereviside every $2 \mathrm{~d}$ (8 $\mathrm{mg}$ dry weight per animal). Under these conditions the animals could be maintained for several months. Zinc uptake rates for the mussels did not change during this period.

Experimental procedures. Experiments were performed in static exposure systems containing 0.51 chemically defined seawater (Table 1). Zinc uptake by individual mussels was measured over a 24 h period. Chemically defined seawater was obtained by dissolving the 7 analytical grade reagents (Merck, Darmstadt, Germany) in deionised water. A dispersion of $1 \times$ $10^{-4} \mathrm{~mol} \mathrm{l}^{-1}$ manganese dioxide was added to the seawater to remove the metal impurities present in the analytical grade reagents. After an equilibration period of $24 \mathrm{~h}$, the dispersion was filtered through a $0.2 \mu \mathrm{m}$ membrane filter to remove the manganese dioxide from the solution (Van den Berg \& Kramer 1979).
Table 1 Composition of 11 chemically defined seawater of salinity $35 \%$. The medium was prepared by dissolving the 7 analytical grade products in deionised water

\begin{tabular}{|lc|}
\hline Element & Amount $(g)$ \\
\hline $\mathrm{NaCl}$ & 23.50 \\
$\mathrm{Na}_{2} \mathrm{SO}_{4}$ & 4.00 \\
$\mathrm{KCl}$ & 0.68 \\
$\mathrm{NaHCO}$ & 0.196 \\
$\mathrm{CaCl}_{2} .2 \mathrm{H}_{2} \mathrm{O}$ & 1.47 \\
$\mathrm{MgCl}_{2} \cdot 6 \mathrm{H}_{2} \mathrm{O}$ & 10.78 \\
$\mathrm{H}_{3} \mathrm{BO}_{3}$ & 0.026 \\
\hline
\end{tabular}

Although mussels were exposed to chemically defined seawater, the complexation properties of the seawater changed during the experimental period. This is due to the fact that the mussels excrete organic compounds (e.g. amino acids) in the water, which increases the complexation capacity of the water. At

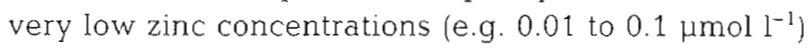
this causes a significant change in the chemical speciation and bioloyical availduility of the metai. To minimise this effect, the mussels were exposed to a higher zinc concentration $\left(5 \mu \mathrm{mol} \mathrm{l}^{-1}\right)$ so that only a small fraction of the zinc was complexed by the organics which accumulated in the water during the experiment.

Seawater zinc concentrations reported in literature typically range from 1.5 to $150 \mathrm{nmol}^{-1}$, but much higher concentrations may be reached in highly polluted areas (Brewer 1975, Martin \& Whitfield 1981, Langston 1990). Exposing mussels to elevated zinc concentrations may cause toxic effects. Toxicity varies strongly with exposure conditions and the developmental stage of the organisms. For adult mussels $96 \mathrm{~h}$ $\mathrm{LC}_{50}$ values of $38 \mu \mathrm{mol} \mathrm{l^{-1 }}$ (Ahsanullah 1976) and $119 \mu \mathrm{mol} \mathrm{l}^{-1}$ (Abel 1976) have been reported. Exposure to zinc also has acute effects at much lower concentrations. Filtration rates decrease when mussels are exposed to concentrations of $7.65 \mu \mathrm{mol} \mathrm{l}^{-1}$ or higher (Abel 1976). Pumping rates decrease when mussels are exposed to concentrations of $4.74 \mu_{\mathrm{mol} \mathrm{l}}^{-1}$ or higher (Redpath \& Davenport 1988). Hence, exposing mussels to $5 \mathrm{\mu mol} \mathrm{l}^{-1}$ zinc could result in responses which may affect metal. uptake rates. To test the effect of $5 \mu_{\mathrm{mol} \mathrm{l}}^{-1}$ zinc on the mussels, filtration rates of control and zinc exposed mussels were measured over a period of $24 \mathrm{~h}$ using the procedure described by Abel (1976). The results showed that filtration rates did not decrease significantly in the zinc exposed mussels. This, together with the fact that zinc uptake remained linear over the $24 \mathrm{~h}$ exposure period, indicates that exposing the mussels to $5 \mu \mathrm{mol} \mathrm{I}^{-1}$ of zinc does not affect uptake rates.

Before each experiment, the mussels were scrubbed to remove epibionts attached to the shells. The expo- 
sure medium was spiked with $296 \mathrm{kBq} \mathrm{I}^{-165}$ Zinc (Amersham Bucks, UK) $24 \mathrm{~h}$ prior to the start of the experiment. The $1 \mathrm{ml}^{65}$ zinc stock solution contained $37 \mathrm{MBq}$ for $1.530 \mathrm{mg}$ zinc. Diluted stock solutions of ${ }^{65}$ zinc were prepared in $1 \mathrm{mmol}^{-1} \mathrm{HCl}$. The mussels were exposed to this medium for $24 \mathrm{~h}$ at $15 \pm 1^{\circ} \mathrm{C}$. $\mathrm{pH}$ was checked before and after the experiment and varied less than 0.1 unit.

After exposure, each mussel was transferred for 20 min to $0.5 \mathrm{l}$ chemically defined seawater to replace the radioactive water contained in the mantle cavity. This seawater contained $5 \mu \mathrm{mol} \mathrm{l}^{-1} \mathrm{ZnCl}_{2}$ and $1 \mathrm{mmol}$ $\mathrm{l}^{-1}$ of the ligand 8-hydroxyquinoline-5-sulfonic acid but no radioactive tracer This ligand was added to remove metal bound to the body surfaces. The whole mussel was placed in a preweighed $18 \mathrm{ml}$ Maxi Vial (Canberra Packard, Meriden, USA) and counted in a Packard Minaxi Auto-Gamma counter (Model 5530) for 1 min to determine ${ }^{b 5}$ zinc activity.

Using a file with a triangular cross section, an insertion was made in the shell at the height of the posterior adductor muscle. The shell valves were slightly pried open with an oyster knife, allowing water to drain off the mantle cavity. Approximately $0.5 \mathrm{ml}$ hemolymph was obtained by directly puncturing the sinus of the posterior adductor muscle using a syringe $10.45 \times$ $12 \mathrm{~mm}$, Terumo Europe, Leuven, Belgium) (Zurburg \& Kluytmans 1980). The shell valves were opened by cutting the posterior adductor muscle. The mussels were dissected for gills and digestive system. The shells were removed and placed in a preweighed Maxi Vial. Hemolymph and the different soft parts were each placed in a $6 \mathrm{ml}$ preweighed Pony Scintillation Vial (Canberra Packard). Fresh weight of the samples was determined and $1 \mathrm{ml}$ of tissue solubiliser (Soluene-350, Canberra Packard) was added to hemolymph, gill and digestive system to obtain a homogeneous sample and improve energy detection in the gamma counter The hemolymph samples were weighed and the total amount of hemolymph was calculated based on the data of Martin et al. (1958) The vials were shaken for $24 \mathrm{~h}$ to promote solubilisation of the tissues. After solubilisation the samples were placed in the gamma counter for 10 min to determine ${ }^{65}$ zinc activity.

Chemical speciation model. To calculate the concentrations and activities of the metal species, a chemical speciation model was constructed. The model calculates the equilibrium speciation from a compilation of the interactions among the components present in the solution (salinity $35 \%, \mathrm{pH} 8.00$, temperature: $15^{\circ} \mathrm{C}$. Stability constants used in the calculations are based on the data of Dickson \& Whitfield (1981) for the major components, and on the data of Smith \& Martell $(1976,1989)$ and Martell \& Smith $(1974,1977,1982)$ for the zinc species. For each species the stability con- stants at different ionic strengths were fitted to an interpolation function that has the form of an extended Debye-Hückel equation (Turner et al. 1981). These fitted equations were used in the computer program Solution (R. Blust \& L. Van Ginneken unpubl.), an adaptation of the program Complex (Ginzburg 1976). Enthalpies to describe the effect of temperature on the equilibrium position of the reactions were taken from Byrne et al. (1988) and Smith \& Martell (1989).

Results of the chemical speciation calculations were expressed on the molar concentration scale and multiplied by the appropriate activity coefficients to obtain species activities. The activity coefficients were based on the data of Millero (1982) for the free zinc ion, and on the data of Sposito \& Traina (1987) for the other zinc species. The thermodynamic stability constants and the stability constants at the ionic strength of seawater are given in Table 2 .

Determination of zinc uptake rates. Measurements of ${ }^{65}$ zinc activity were used to calculate zinc uptake rates. Radioactive zinc was measured in a preset energy window (165 to $1300 \mathrm{keV}$ ). Stock solutions

Table 2. Thermodynamic and conditional stability constants for the zinc species considered in the chemical speciation model. K: thermodynamic statbility constants: $Q$ : conditional stability constants (salinity $35 \% ; \mathrm{pH} 8.00$; temperature $15^{\circ} \mathrm{C}$ )

\begin{tabular}{|c|c|c|}
\hline Species & $\log K$ & $\log Q$ \\
\hline $\mathrm{Zn}^{2+}$ & - & - \\
\hline $\mathrm{ZnOH}^{+}$ & 4.99 & 4.58 \\
\hline $\mathrm{Zn}(\mathrm{OH})_{2}{ }^{0}$ & 10.20 & 9.00 \\
\hline $\mathrm{Zn}(\mathrm{OH})_{3}$ & 13.90 & 13.06 \\
\hline $\mathrm{Zn}(\mathrm{OH})_{4}{ }^{2-}$ & 15.50 & 15.49 \\
\hline $\mathrm{ZnCl}^{+}$ & 0.53 & -0.17 \\
\hline $\mathrm{ZnCl}_{2}{ }^{\circ}$ & 0.69 & -0.19 \\
\hline $\mathrm{ZnCl}_{3}^{-}$ & 0.70 & -0.29 \\
\hline $\mathrm{ZnCl}_{4}{ }^{2-}$ & 0.32 & -0.37 \\
\hline $\mathrm{ZnSO}_{4}{ }^{\circ}$ & 2.32 & 0.94 \\
\hline $\mathrm{Zn}\left(\mathrm{SO}_{4}\right)_{2}{ }^{2-}$ & 3.26 & 1.66 \\
\hline $\mathrm{Zn}\left(\mathrm{SO}_{4}\right)_{3}^{4}$ & 2.03 & 1.84 \\
\hline $\mathrm{ZnCO}_{3}{ }^{0}$ & 5.10 & 3.83 \\
\hline $\mathrm{ZnHCO}_{3}{ }^{+}$ & 11.03 & 9.72 \\
\hline ZnCIT & 6.07 & 5.09 \\
\hline $\mathrm{ZnHClT}{ }^{0}$ & 10.00 & 8.12 \\
\hline $\mathrm{Zn}(\mathrm{CIT})_{2}{ }^{4-}$ & 7.22 & 6.51 \\
\hline ZnGLY' & 5.38 & 4.85 \\
\hline $\mathrm{Zn}(\mathrm{GLY})_{2}{ }^{0}$ & 9.81 & 9.02 \\
\hline $\mathrm{Zn}(\mathrm{GL} Y)_{3}^{-}$ & 12.30 & 11.48 \\
\hline $\mathrm{ZnH} \mathrm{His}^{\circ}$ & 6.88 & 6.38 \\
\hline $\mathrm{ZnHHis}{ }^{2 *}$ & 11.60 & 11.60 \\
\hline $\mathrm{Zn}(\mathrm{His})_{2}{ }^{0}$ & 12.67 & 11.88 \\
\hline ZnNTA & 12.04 & 10.12 \\
\hline $\mathrm{Zn}(\mathrm{NTA})_{2}^{4}$ & 15.02 & 13.95 \\
\hline $\mathrm{ZnEDTA}{ }^{2}$ & 17.94 & 16.37 \\
\hline $\mathrm{ZnHEDTA}^{-}$ & 20.09 & 19.53 \\
\hline ZnOHEDTA? & 19.75 & 18.38 \\
\hline $\mathrm{ZnH}_{2} \mathrm{EDTA}^{n}$ & 22.79 & 20.07 \\
\hline
\end{tabular}


were used for the construction of a calibration curve, so that the counting efficiency could be determined. The counts per minute (CPM) were corrected for background and radioactive decay. ${ }^{65} \mathrm{Zinc}$ can be determined with a $17.8 \%$ counting efficiency in a Minaxi Auto-Gamma counting system fitted with a 3 inch thallium activated sodium iodide crystal. The counting efficiency gives the relation between CPM and the disintegrations per minute (DPM) of ${ }^{65}$ zinc.

Zinc $^{2+}$ uptake (nmol $\mathrm{g}^{-1} \mathrm{~h}^{-1}$ ) was calculated according to the formula:

$$
\text { Zinc }^{2+} \text { uptake }=\frac{\text { DPM }^{63} Z n}{W \times t \times S A \times 60}
$$

in which $W$ is the fresh weight $(g), t$ is the exposure time (hours), $S A$ is the specific activity (Bq $\left.\mathrm{nmol}^{-1}\right)$ and 60 is a constant factor to transform DPM to $\mathrm{Bq}(1 \mathrm{~Bq}=$ 1 disintegration per second and $1 \mathrm{~Bq}=60 \mathrm{DPM}$ ).

Upidke oi zinc as function of time and conceniration. To test the linearity of uptake in function of time and concentration, 2 preliminary experiments were conducted. In a first experiment accumulation of zinc by mussels cxposed to 5 $\mu \mathrm{mol} \mathrm{I} \mathrm{I}^{-1} \mathrm{ZnCl}_{2}$ was followed for $24 \mathrm{~h}$. After 1 , $3,6,12$ and $24 \mathrm{~h}$ the mussels were transferred to a rinsing solution for $20 \mathrm{~min}$ and processed. Preliminary experiments showed that this period was sufficient to remove the rapidly exchangeable pool of zinc adsorbed on the external surfaces of the animal. In a second experiment accumulation of zinc was followed in solutions containing 1 to 20 $\mu \mathrm{mol} \mathrm{l}^{-1} \mathrm{ZnCl}_{2}$ over a $24 \mathrm{~h}$ period. The same experimental procedures were followed as described previously.

Uptake of zinc in complexing environments. To determine the effect of complexation on the uptake of zinc, 5 organic ligands (EDTA, NTA, histidine, citrate and glycine) were used. The differences in stability constants between the zinc-ligand complexes generated a wide range of free zinc ion activities. The ligands were added to the solutions from concentrated stocks prepared in deionised water. The experiments were performed in either the absence or presence of a metal ion buffer. In the first case, $5 \mu \mathrm{mol}$ $\mathrm{l}^{-1} \mathrm{ZnCl}_{2}$ and a fixed concentration of one of the ligands was added. Each of the 5 ligands were tested for 9 different concentrations. In the second case, an excess of $\mathrm{ZnCl}_{2}\left(1 \times 10^{-4}\right.$ mol $\left.\mathrm{l}^{-1}\right)$ and EDTA $\left(9.55 \times 10^{-5} \mathrm{~mol} \mathrm{l}^{-1}\right)$ and a fixed concentration of one of the ligands was added, so that the same free zincion activity in both buffered and non-buffered environ- ments was obtained. The same experimental procedures were followed as described previously.

Statistical analysis. Regressions, correlations and analyses of variance (ANOVA) were performed with Statistica (StatSoft Inc., Tulsa, OK, USA).

\section{RESULTS}

\section{Uptake of zinc as function of time and concentration}

In a first experiment uptake of zinc was followed in mussels exposed to $5 \mu \mathrm{mol} \mathrm{l}^{-1}$ zinc over $24 \mathrm{~h}$ (Fig. 1). The uptake of zinc by the soft tissues increases linearly with time of exposure during the first $24 \mathrm{~h}$. The slope $(v)$ of the absorption curve is the zinc uptake rate $\left(v_{\text {gill }}=0.188 \mathrm{nmol} \mathrm{g}^{-1} \mathrm{~h}^{-1}, v_{\text {hemolymph }}=0.017 \mathrm{nmol}\right.$ $\left.\mathrm{g}^{-1} \mathrm{~h}^{-1}\right)$. Adsorption of zinc by the shell does not remain fuliy linear, indicating sdiurdtion of the shell binding sites.

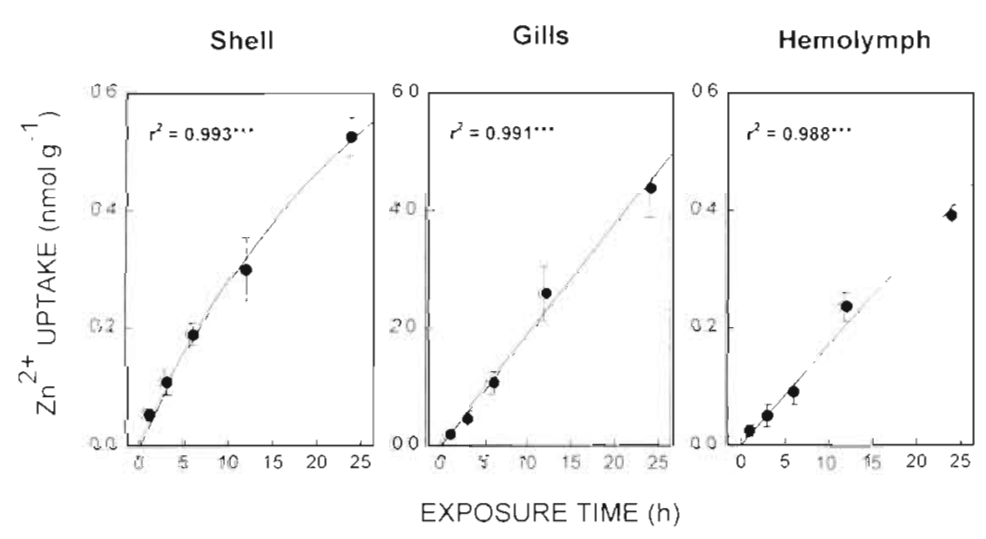

Fig. 1. Mytilus edulis. Uptake of zinc by shell, gills and hemolymph as function of exposure tume (total $\mathrm{Zn}$ : $5 \mu \mathrm{mol} \mathrm{l}^{-1}$ ). Data points represent means for 7 replicates with standard deviations. $\cdots p \leq 0.001$

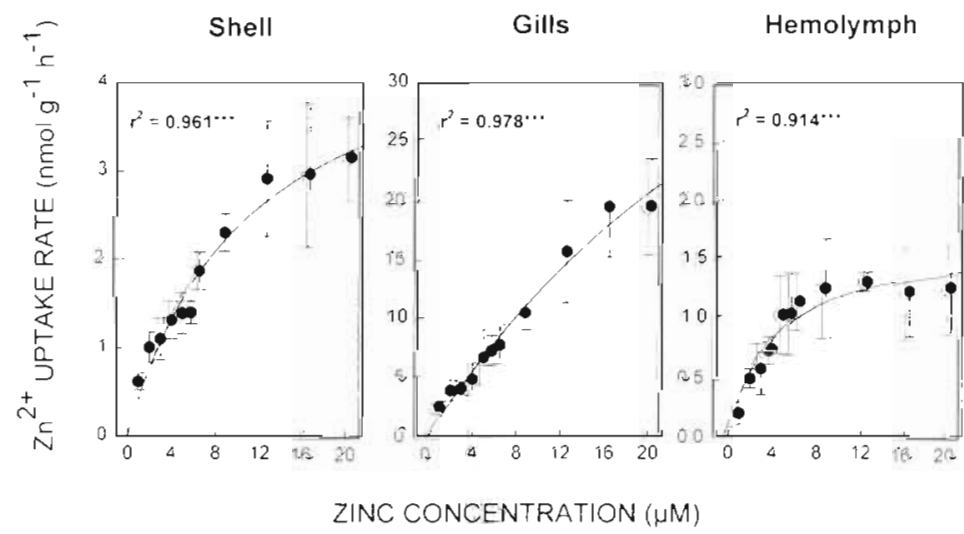

Fig. 2. Mytilus edulis. Uptake of zinc by shell, gllls and hemolymph as function of the total zinc concentration (exposure time: 24 h). Data points represent means for 7 replicates with standard deviations. $\cdots p \leq 0.001$ 
Fig. 3. Effect of complexation by 5 organic ligands (EDTA, NTA, histidine, citrate and glycine) on the chemical speciation of zinc in seawater containing $5 \mu \mathrm{mol} \mathrm{l^{-1 }}$ zinc (salinity 35\%; pH 8.00; temperature $\left.15^{\circ} \mathrm{C}\right)$
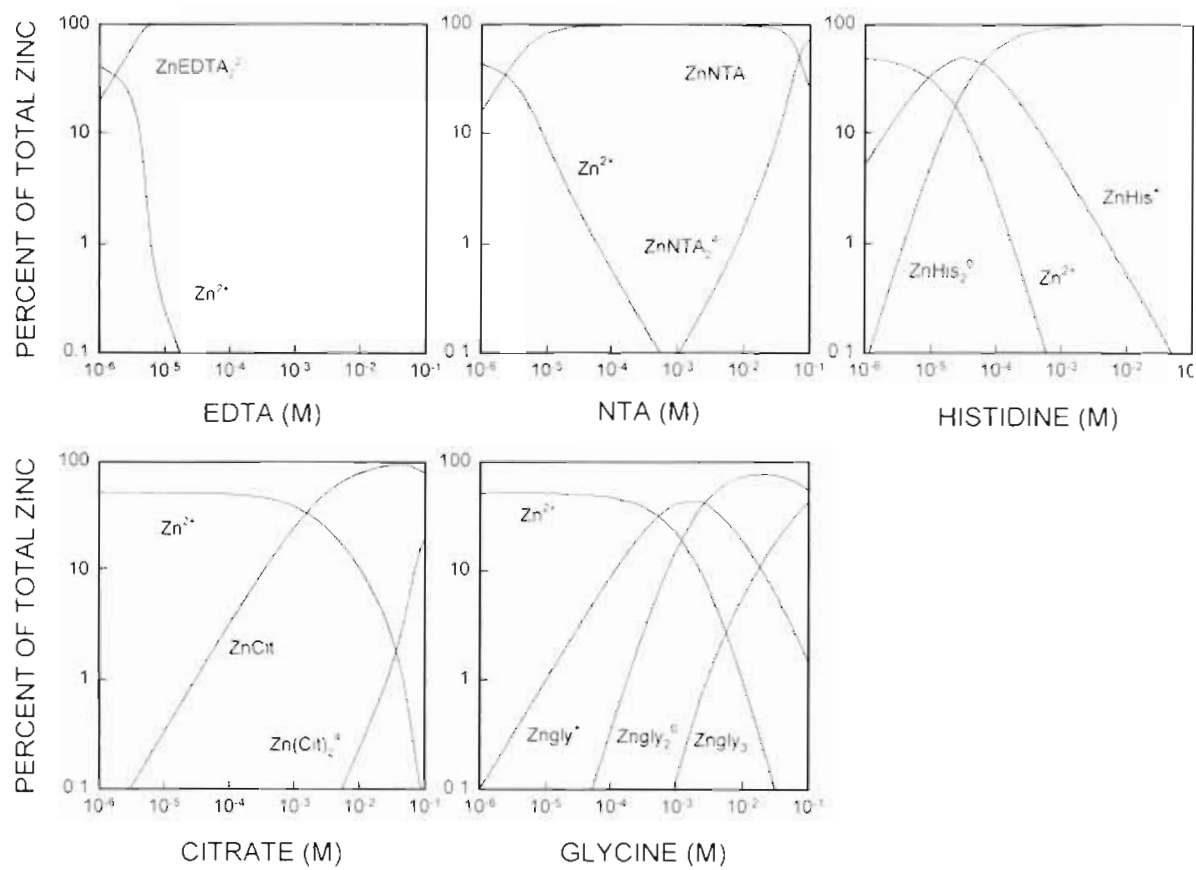

HISTIDINE (M)

Table 3. Mytilus edulis. Relative importance of different organs for zinc uptake ( $\mathrm{n}=35$; total zinc concentration: $5 \mu \mathrm{mol} \mathrm{l}^{-1}$ )

\begin{tabular}{|lc|}
\hline $\begin{array}{l}\text { (A) Zinc uptake per gram fresh weight } \pm \text { SD } \\
\text { Organ } \\
\text { Zinc uptake }\left(\mathrm{nmol} \mathrm{g} \mathrm{g}^{-1} \mathrm{~h}^{-1}\right)\end{array}$ \\
\hline Digestive system & $10.3 \pm 3.5$ \\
Gills & $5.3 \pm 1.4$ \\
Mantle & $4.6 \pm 2.7$ \\
Foot & $2.9 \pm 0.9$ \\
Muscle & $2.2 \pm 0.8$ \\
Hemolymph & $1.3 \pm 0.5$ \\
& \\
(B) Absolute zinc uptake in different tissues \pm SD \\
Organ & Zinc uptake (nmol h-1) \\
\hline Hemolymph & $0.2 \pm 0.1$ \\
Muscle & $0.11 \pm 0.04$ \\
Digestive system & $0.09 \pm 0.03$ \\
Gills & $0.05 \pm 0.01$ \\
Mantle & $0.02 \pm 0.01$ \\
Foot & $0.004 \pm 0.001$ \\
\end{tabular}

In a second experiment uptake of zinc was determined after $24 \mathrm{~h}$ of exposure to different zinc concen-

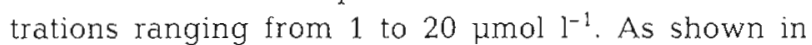
Fig. 2, a rectangular hyperbola yielded a good fit to the data, indicating that zinc uptake displays saturable uptake kinetics. Uptake in gills remained linear up to a zinc concentration of $16 \mu \mathrm{mol} \mathrm{l}^{-1}$ and uptake in hemolymph remained linear up to a zinc concentration of $5 \mu \mathrm{mol} \mathrm{l^{-1 }}$. These 2 experiments show that zinc uptake by the tissues does not saturate over a $24 \mathrm{~h}$ period for mussels exposed to $5 \mu_{\mathrm{mol}}^{-1}$ zinc. There- fore the following experiments were conducted over this time interval and at this zinc concentration. Table 3 shows the relative and absolute distribution of zinc in the different organs after $24 \mathrm{~h}$ of exposure to $5 \mu \mathrm{mol} \mathrm{l} \mathrm{l}^{-1}$ zinc.

\section{Chemical speciation model}

The results of the chemical speciation calculations are shown in Fig. 3. In chemically defined seawater of $\mathrm{pH} 8.0$, salinity $35 \%$ and temperature $15^{\circ} \mathrm{C}$, zinc is distributed over the following inorganic complexes: $52 \%$ as the free $\mathrm{Zn}^{2+}$ ion, $33.5 \%$ as chloro-complexes, $6 \%$ as carbonate complexes, $4.5 \%$ as sulphate complexes and $4 \%$ as hydroxide complexes. The addition of an organic ligand decreases the free zinc concentration by the formation of several organic complexes. For the weakest ligands, like glycine, an excess of ligand must be added before the metal is completely complexed. For stronger ligands, like EDTA, the metal is already completely complexed at an equimolar concentration of ligand and metal.

\section{Uptake of zinc in non-metal buffered complexing environments}

Zinc uptake experiments were performed in chemically defined seawater with a fixed total zinc concentration of $5 \mu \mathrm{mol} \mathrm{^{-1 }}$ and 9 different concentrations of ligand. The 45 combinations generated a wide range 
of free zinc ion activities ranging from $1.5 \times 10^{-11}$ to $5.5 \times 10^{-7} \mathrm{~mol} \mathrm{l}^{-1}$. In Fig. 4 the zinc uptake rates are plotted against the zinc ion activity in the seawater for digestive system, gills and hemolymph. In the 3 organs the uptake increases with. increasing free zinc ion activity.

The correlations between the free zinc ion activity and the zinc uptake rates presented in Table 4 show that there is a high degree of linear association between the 2 variables. The correlations between the activities of the zinc complexes and the zinc uptake rates are negative, implying that complexation decreases uptake. However, in the case of histidine the correlations between the activity of $\mathrm{ZnHis}^{+}$and zinc uptake rates are significantly positive, indicating that ZnHis ${ }^{+}$promotes zinc uptake.

The results of a multiple linear regression analysis concerning the effect of histidine on zinc uptake are yiven in Tabie 5. Considering the free zinc ion as the only species that is taken up by the mussel explains between 54 and $71 \%$ of the variation observed, depending on the organ considered. Including the ZnHis ${ }^{+}$complex in the model explains betweeñ 84 and

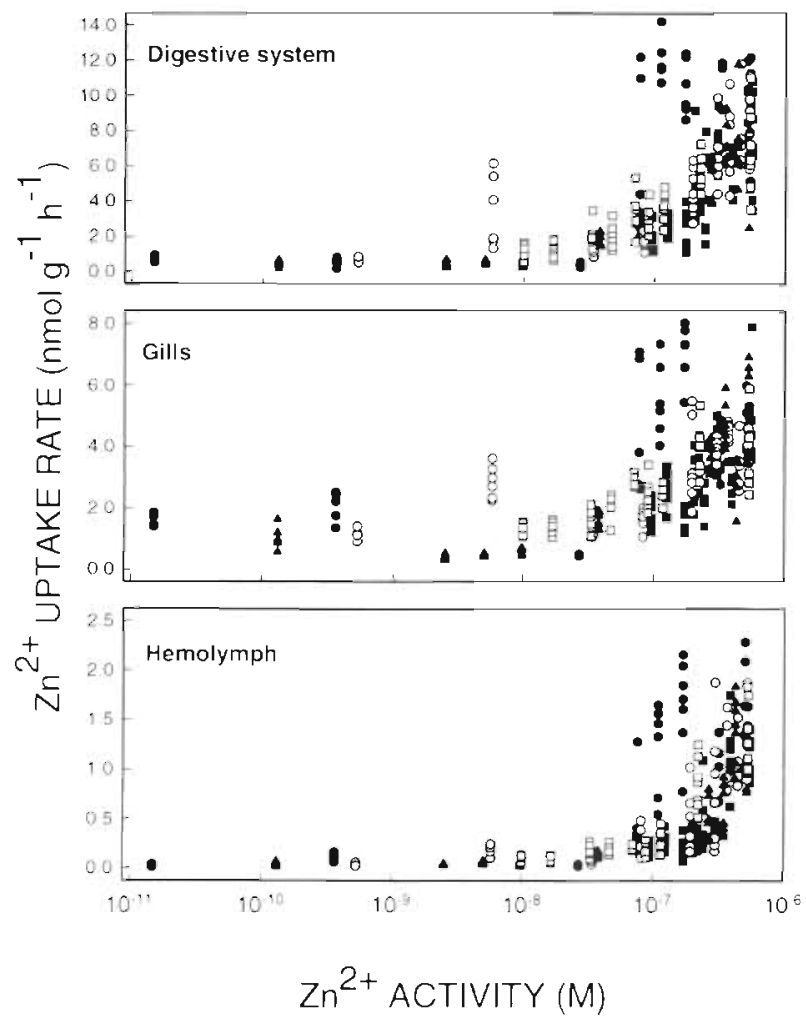

Fig. 4. Mytilus edulis. Uptake of zmc by digestive system, gills and hemolymph. Effect of organic complexation on the zinc uptake rate in function of the free zinc ion activity in a solution containing $5 \mu \mathrm{mol} \mathrm{L}^{-1}$ zinc. (salinity $35^{\circ} ; \mathrm{pH} 8.00_{i}$ temperature $15^{\circ} \mathrm{C}$ ). (ム) EDTA; (O) NTA; (•) histidine; (D) glycine; ( $)$ citrate
Table 4. Mytilus edulis. Coefficients of determination $\left(r^{2}\right)$ for linear correlations between the activities of the different zinc species in solution and the zinc uptake rate for hemolymph, gills and digestive system. The different complexes are represented by $\mathrm{ZnL}$, where $\mathrm{L}$ indicates the ligand used (EDTA, NTA, histidine, citrate, glycine) and $i$ the number of ligands in the complex. Sign in front of determination coefficient designates whether the correlation is positive or negative. Significance levels indicated according to the following probability ranges: ${ }^{n} \mathrm{p}>$ $0.05_{i} \cdot 0.05 \geq p>0.01_{i}{ }^{\cdots} 0.01>p>0.001_{i}{ }^{\cdots} \cdot p \leq 0.001$

\begin{tabular}{|c|c|c|c|c|}
\hline & $\mathrm{Zn}^{2 *}$ & $\mathrm{ZnL}$ & $\mathrm{ZnL}_{2}$ & $n$ \\
\hline \multicolumn{5}{|c|}{ Hemolymph } \\
\hline EDTA & $0.75 \cdots$ & $-0.75 \cdots$ & & 57 \\
\hline NTA & $0.70^{\cdots} \cdot$ & $-0.70 \cdots$ & $-0.14^{\circ}$ & 59 \\
\hline Histidine & $0.45 \cdots$ & $0.02^{n s}$ & $-0.61 \cdots$ & 53 \\
\hline Citrate & $0.66 \cdots$ & $-0.66 \cdots$ & $-0.34 \cdots$ & 58 \\
\hline Glycine & $0.83 \cdots$ & $-0.13^{\circ}$ & $-0.71 \cdots$ & 60 \\
\hline \multicolumn{5}{|l|}{ Gills } \\
\hline EDTA & $0.77^{\cdots}$ & $-0.77 \cdots$ & & 62 \\
\hline NTA & $0.56 \cdots$ & $-0.56 \cdots$ & $-0.25 \cdots$ & 60 \\
\hline Histidine & $0.10^{\circ}$ & $0.16^{\cdots}$ & $-0.33 \cdots$ & 60 \\
\hline Citrate & $0.36^{\cdots}$ & $-0.36 \cdots$ & $-0.29 \cdots$ & 61 \\
\hline Glycine & $0.52 \cdots$ & $-0.00^{\mathrm{ns}}$ & $-0.70 \cdots$ & 62 \\
\hline \multicolumn{5}{|c|}{ Digestive system } \\
\hline EDTA & $0.79 \cdots$ & $-0.79 \cdots$ & & 62 \\
\hline NTA & $0.72 \cdots$ & $-0.73 \cdots$ & $-0.22 \cdots$ & 60 \\
\hline Histidine & $0.36^{\cdots} \cdot$ & $0.08^{\circ}$ & $-0.64 \cdots$ & 59 \\
\hline Citrate & $0.42 \cdots$ & $-0.42 \cdots$ & $-0.42 \cdots$ & 60 \\
\hline Glycine & $0.64 \cdots$ & $-0.04^{\mathrm{ms}}$ & $-0.73 \cdots$ & 61 \\
\hline
\end{tabular}

$87 \%$ of the variation. Also including the $\mathrm{Zn}(\mathrm{His})_{2}{ }^{\circ} \mathrm{com}-$ plex in the model does not decrease the amount of variation explained by the model.

To test whether there are differences among the 5 groups in zinc uptake, a linear regression model through the origin was fitted to the data for each of the 5 ligands. The model was fitted through the origin since there is no zinc uptake if there is no zinc in the medium. A convenient method for systematically comparing all pairs of regression slopes is to compute upper and lower confidence limits for each regression slope such that 2 slopes are significantly different when their limits do not overlap (Gabriel 1978). Regression slopes whose confidence intervals overlap are not significantly different at the experimentwise error rate of $\alpha=0.05$. Those whose intervals do not overlap are significantly different. The regression slopes and their intervals for the 5 different Jigands for digestive system, gills and hemolymph are shown in Fig. 5.

\section{Uptake of zinc in metal buffered complexing environments}

Metal ion buffers provide a controlled source of free metal ions. If free metal ions are removed from the 


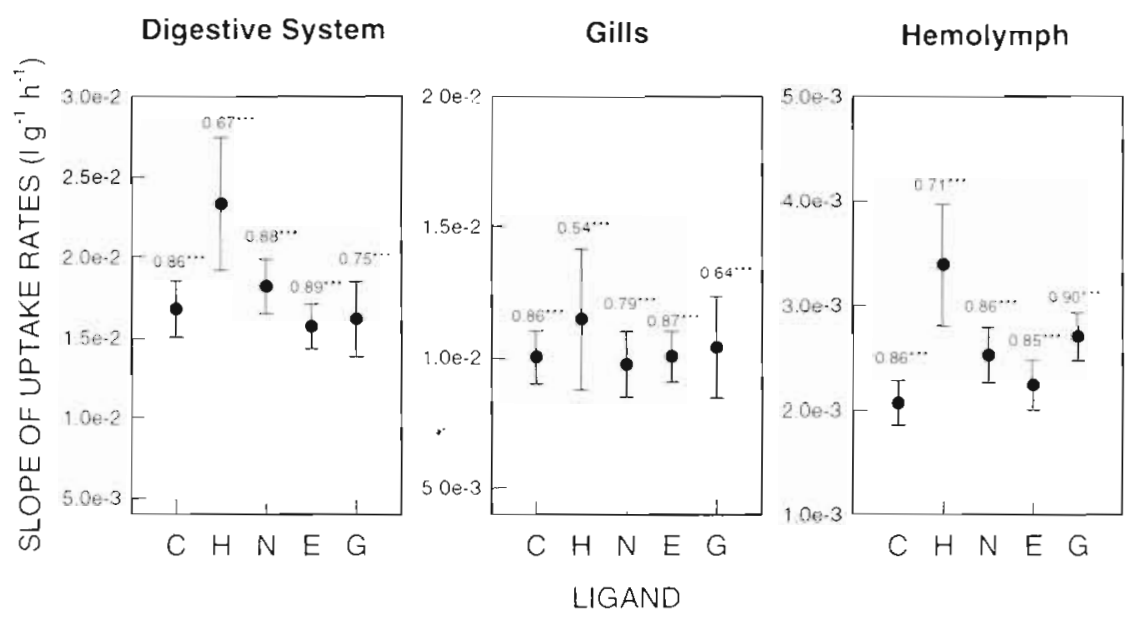

Fig. 5. Mytilus edulis. 95\% comparison intervals for the slopes of zinc uptake rate on free zinc ion activity for digestive system, gills and hemolymph. Regression coefficients whose intervals do not overlap are significantly different. The coefficients of determination $\left(\mathrm{r}^{2}\right)$ for the linear regression through the origin between the free zinc ion activity (nM) and the zinc uptake rate (nmol $\mathrm{g}^{-1} \mathrm{~h}^{-1}$ ) are given for each ligand. E: EDTA; N: NTA; $\mathrm{H}$ : histidine; C: citrate; G: Glycine. $\cdots p \leq 0.001$

Table 5. Mytilus edulis. Fitting parameters $\left(\mathrm{C}_{1}, \mathrm{C}_{2}, \mathrm{C}_{3}\right)$ and coefficients of determination $\left(\mathrm{r}^{2}\right)$ for multiple linear regression between the activities of the free zinc ion, the different zinc-histidine species and the zinc uptake rate for hemolymph, gills and digestive system. Concentrations of zinc species are in nmol $\mathrm{l}^{-1}$ and uptake rates in $\mathrm{nmol} \mathrm{kg} \mathrm{kg}^{-1} \mathrm{~h}^{-1}$. Significance levels indicated according to the following probability ranges: ${ }^{n s} \mathrm{p}>0.05 ; \cdot 0.05 \geq \mathrm{p}>0.01$; $\cdots 0.01>p>0.001_{i} \cdots p \leq 0.001$

\begin{tabular}{|c|c|c|c|c|c|}
\hline & $\mathrm{C}_{1}$ & $\mathrm{C}_{2}$ & $\mathrm{C}_{3}$ & $\mathrm{n}$ & $r^{2}$ \\
\hline \multicolumn{6}{|c|}{$\mathrm{Zn}$ uptake $=\mathrm{C}_{1} \times \mathrm{Zn}^{2+}$} \\
\hline Hemolymph & $3.390 \cdots$ & & & 53 & $0.71 \cdots$ \\
\hline Gills & $11.475 \cdots$ & & & 60 & $0.54 \cdots$ \\
\hline Digestive System & $23.310^{\cdots}$ & & & 59 & $0.67 \cdots$ \\
\hline \multicolumn{6}{|c|}{$\mathrm{Zn}$ uptake $=\mathrm{C}_{1} \times \mathrm{Zn}^{2+}+\mathrm{C}_{2} \times \mathrm{ZnHIS}^{+}$} \\
\hline Hemolymph & $2.789 \cdots$ & $0.345 \cdots$ & & 53 & $0.84 \cdots$ \\
\hline Gills & $7.620 \cdots$ & $2.234^{\cdots}$ & & 60 & $0.85 \cdots$ \\
\hline Digestive System & $17.910 \cdots$ & $3.295 \cdots$ & & 59 & $0.87 \cdots$ \\
\hline \multicolumn{6}{|c|}{ Zn uptake $=\mathrm{C}_{1} \times \mathrm{Zn}^{2+}+\mathrm{C}_{2} \times \mathrm{ZnHIS}^{+}+\mathrm{C}_{3} \times \mathrm{ZnHIS}_{2}^{0}$} \\
\hline Hemolymph & $2.770^{\cdots}$ & $0.369 \cdots$ & $-0.033^{n s}$ & 53 & $0.83 \cdots$ \\
\hline Gills & $7.794 \cdots$ & $2.034 \cdots$ & $0.273^{m}$ & 60 & $0.86 \cdots$ \\
\hline Digestive System & $17.729 \cdots$ & $3.511 \cdots$ & $-0.288^{\mathrm{ns}}$ & 59 & $0.83 \cdots$ \\
\hline
\end{tabular}

uptake in the presence of histidine is far above what is expected from the free zinc ion activity in the solution.

\section{DISCUSSION}

During the first 24 h zinc uptake increases linearly with the time of exposure. Hence, a constant concentration gradient is maintained across the exchange surfaces during at least the first $24 \mathrm{~h}$ of metal uptake. Pentreath (1973) and Renfro et al. (1975) followed zinc accumulation and showed that uptake remained linear over the first 2 to $3 \mathrm{~d}$ of exposure and that a steady state situation was only reached after 3 to $4 \mathrm{wk}$.

As shown in Table 3 the gills and the digestive system are the most important organs for zinc uptake. The gills and the digestive system of bivalve molluscs are

solution, by adsorption or absorption, they are replenished by the reversible dissociation from the reservoir of metal in the buffer complex. Fig. 6 gives the results of the uptake in non-metal buffered and metal buffered environments for gills, digestive system and hemolymph. The different groups were tested by 1-way ANOVA followed by Tukey Kramer multiple comparisons test. For gills the uptake of zinc is comparable for both environments. In contrast uptake of zinc by the digestive system and hemolymph is much higher in metal buffered environments. As before, histidine appears to enhance the uptake of zinc, since known to be critical organs for the uptake and accumulation of metal ions from seawater (Pentreath 1973 , Janssens \& Scholz 1979, Amiard et al. 1986). Considering the absolute amounts of zinc, hemolymph becomes the most important compartment, since it is the largest soft body compartment. The blood volume of Mytilus californianus is about $51 \%$ of the wet weight of the soft tissues (Martin et al. 1958).

The relation between the total zinc concentration in the exposure medium and zinc uptake rate followed a hyperbolic curve. This means that zinc uptake is a saturable process, indicating that a membrane transport 


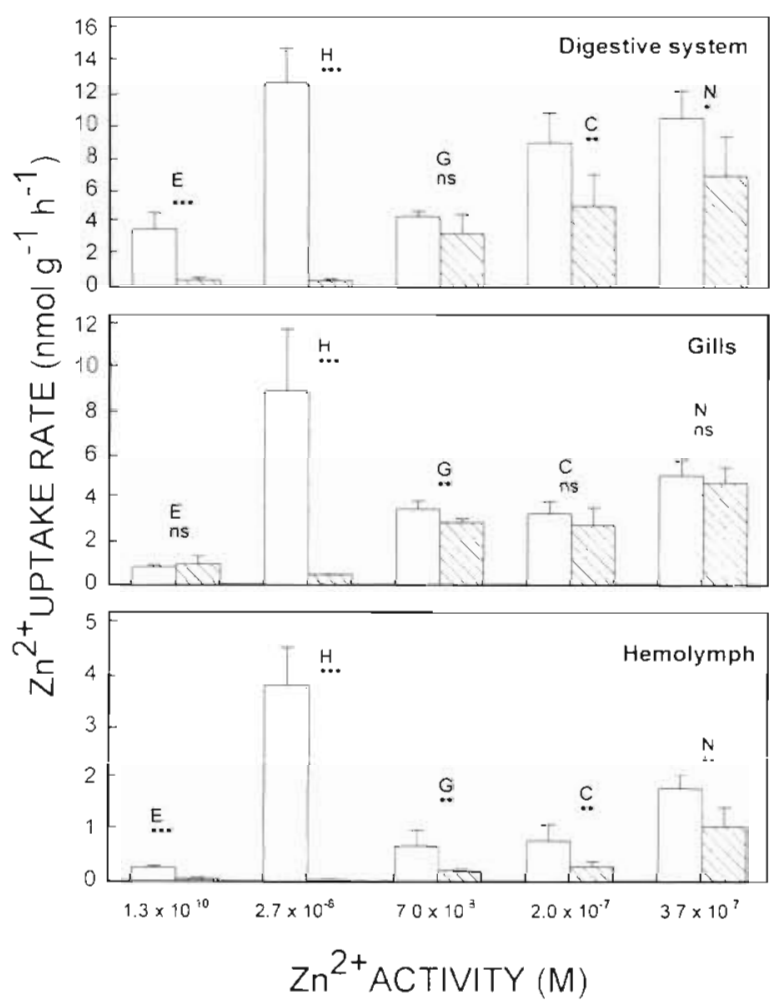

Fig. 6. Mytilus edulis. Comparison of the zinc uptake rate by digestive system, gills and hemolymph in metal buffered (open bars) and non-metal buffered (striped bars) solutions at the same free zinc ion activities. E: EDTA; N: NTA; $H$ : histidine; $C$ : citrate; G: glycine. Significance levels indicated according to the following probability ranges: ${ }^{n s} p>0.05$; $\cdot 0.05 \geq p>0.01 ; \cdot 0.01>p>0.001 ; \cdots p \leq 0.001$

system, i.e. a channel or carrier, takes the metal across the lipid bilayer. Such a system can be described by Michaelis-Menten kinetics which characterises the system by 2 parameters: $V_{\max }$ and $K_{\mathrm{m}}$. $V_{\max }$ is the maximum velocity and $K_{\mathrm{m}}$, in physical terms, can be thought of as a measure of the affinity of the transporter for the metal. The lower the $K_{\mathrm{m}}$ value, the higher the affinity (Palmer 1991). The values for $V_{\text {max }}$ and $K_{m}$ in gills and hemolymph are respectively 65.9 and $1.7 \mathrm{nmol} \mathrm{g}^{-1} \mathrm{~h}^{-1}$ and 44.03 and $4.1 \mu \mathrm{mol} \mathrm{l}^{-1}$ This means that zinc uptake is much faster in gills than in hemolymph. The affinity of the transporter which takes the metal from the epithelia to the hemolymph is much higher than the affinity of the transporter which takes the metal from the solution across the apical gill membrane.

Transport of metal ions across apical membranes is generally considered to be passive, involving the passage of the metal through size and charge selective channels. The interactions of the metal ion with the channel are rather weak, involving mainly electrostatic forces. The transport of metal ions across the baso- lateral membranes is generally considered to be an active process, involving stronger covalent interactions between the metal and the carrier In general rates of channel transport are also higher than carrier mediated transport (Friedman 1986).

A number of previous studies have demonstrated the importance of the free metal ion activity in the bioavailability of trace metals to aquatic organisms (Zamuda \& Sunda 1982, Jenkins \& Sanders 1986, Blust et al. 1992). Specifically for mussels, some studies demonstrated an increase in metal uptake in the presence of organic ligands (George \& Coombs 1977. Pempkowiak et al. 1989). However, the current study shows that organic ligands decrease metal uptake by reducing the bioavailable form of the metal, i.e. the free metal ion. In all cases, except histidine, there is a negative correlation between the activities of the zincligand complexes and the uptake rates. This indicates that the metai complexes are poorly avallable or not available to the animal. However, a direct relation between the free zinc ion activity and zinc uptake rate is not always apparent over the entire range of complexation conditions.

The observed differences can be caused by changes in the chemical speciation of the metals in the layers lining the exchange surfaces where conditions may deviate considerably from seawater. This is certainly true for the digestive tract, which secretes Iarge amounts of mucus and digestive enzymes (Morton 1992).

The kinetics of metal complexation can also influence metal uptake when the rate of complex dissociation is slower than the rate of metal uptake. In this case the metal transporting system may deplete the surrounding solution of free zinc so that the rate of metal uptake decreases. Generally the rate of complex dissociation decreases with the thermodynamic stability constants of the metal ligand complex. Thus, for the same free metal ion activity, the rate of metal uptake should decrease with the thermodynamic stability of the metal complexes. Such a dependence was not observed, indicating that zinc uptake is not constrained by complexation kinetics (Hering \& Morel 1990).

In the case of histidine most of the variation in zinc uptake can be explained when the free zinc ion and a zinc-histidine complex are considered to be the metal species that are taken up. Zinc forms 2 different complexes with histidine, i.e. $\mathrm{ZnHis}^{+}$and $\mathrm{Zn}$ (His) ${ }_{2}{ }^{0}$. At low histidine concentrations $\mathrm{ZnHis}^{+}$is the prevalent complex while at higher histidine concentrations the $\mathrm{Zn}$ (His) ${ }_{2}{ }^{\circ}$ complex becomes more important. Formation of the $\mathrm{Zn}(\mathrm{His})_{2}{ }^{0}$ complex results in a decrease of zinc uptake, indicating that only the $\mathrm{ZnHis}^{+}$complex facilitates the uptake of zinc. Previous studies have 
shown that histidine increased the rate of copper uptake by facilitating the delivery of the metal to the copper transporting molecule on the membrane surface (Ettinger et al. 1986). Other authors proposed the direct cellular uptake of zinc-histidine complexes, via an amino acid transport system (Gachot et al. 1991, Aiken et al. 1992). Whether the mechanism of facilitation involves the direct tranport of the $\mathrm{ZnHis}^{+}$complex across the membrane cannot be deduced from the present study

Zinc uptake rates in gills are not significantly different for the 5 ligands used. The slopes of the regression lines of zinc uptake by digestive system and hemolymph are not significantly different for citrate, glycine, NTA and EDTA. However the slope of the regression line for histidine is significantly different from the slopes of the other lines. This is the result of the contribution of $\mathrm{ZnHis}^{+}$to the zinc uptake rate. As a consequence the fit is rather poor which is reflected in the broad confidence limit.

Comparing zinc uptake in non-buffered and buffered environments shows that, for gills, uptake is comparable in both environments and proportional to the free zinc ion activity in the water for all ligands except histidine. This confirms the observation that histidine facilitates the uptake of zinc. In the digestive system zinc uptake is higher in the buffered environment, indicating that zinc is released from the ligands and the free zinc ion activity increases accordingly. The magnitude of the effect varies strongly with the ligand considered so that the relation between the free zinc ion activity and zinc uptake is totally lost under these conditions. Since hemolymph receives metal from both uptake sites, uptake of zinc in this compartment is also higher in a buffered than in a nonbuffered environment.

This study has shown that uptake of zinc strongly depends on the chemical speciation of zinc in the solution. Complexation of zinc with organic ligands may increase or decrease zinc uptake depending on the ligand involved. Most ligands decrease zinc availability by reducing the activity of the free zinc ion in the solution, but there is a marked exception. Histidine appears to promote the uptake of zinc even in the presence of a strong chelator. For the same free zinc ion activity the availability of zinc is higher in the digestive system than in the gills, indicating that zinc is released from its complexes when it enters the gut.

Acknowledgements. R.B. is a Research Associate of the Natronal fund for Screntitic Kesearch of Beigium. This work was sponsored by the Federal Office for Scientific, Technical and Cultural Affairs (O.S.T.C.), Marine Sciences Program (contract number MS/05/011).

\section{LITERATURE CITED}

Abel PD (1976) Effects of some pollutants on the filtration rate of Mytilus. Mar Pollut Bull 7:228-231

Ahrland S (1985) lnorganic chemistry of the ocean. In: Irgolic KJ, Martell AE (eds) Environmental inorganic chemistry. VCH Publishers. Inc, Deerfield Beach, FL, p 65-88

Ahsanullah M (1976) Acute toxicity of cadmium and zinc to seven invertebrate species from Western Port, Victoria J Mar Freshwat Res 27:187-196

Aiken SP, Horn NM, Saunders N (1992) Effects of amino acids on zinc transport in rat erythrocytes. J Physiol 445:69-80

Amard JC, Amard-Triquet C, Berthet B, Metayer C (1986) Contribution to the ecotoxicological study of cadmium, lead, copper and zinc in the mussel Mytilus edulis. Mar Biol 92:7-13

Blust R, Kockelbergh E, Baillieul M (1992) Effect of salinity on the uptake of cadmium by the brine shrimp Artemia franciscana. Mar Ecol Prog Ser 84:245-254

Brewer PG (1975) Minor elements in sea water. In: Riley JP, Skirrow G (eds) Chemical oceanography, Vol 1. Academic Press, New York, p 415-496

Bruland KW (1989) Complexation of zinc by natural organic ligands in the central North Pacific. Limnol Oceanogr 34.(2):269-285

Byrne RH, Kump LR, Cantrell KJ (1988) The influence of temperature and $\mathrm{pH}$ on trace metal speciation in seawater. Mar Chem 25:163-181

Dickson AG, Whitfield M (1981) An ion-association model for estimating acidity constants (at $25^{\circ} \mathrm{C}$ and 1 atm pressure) in electrolyte mixtures related to seawater (ionic strength $1 \mathrm{~mol} \mathrm{~kg}^{-1}$ ). Mar Chem 10:315-333

Ettinger MJ, Darwish HM, Schmitt RC (1986) Mechanism of copper transport from plasma to hepatocytes. Fed Proc 45: $2800-2804$

Farrington JW, Davies AC, Tripp BW, Phelps DK, Galloway WB (1987) 'Mussel Watch' measurements of chemical pollutants in bivalves as one indicator of coastal environmental quality. In: Boyle TP (ed) New approaches to monitoring aquatic ecosystems, ASTM STP 940. American Society for Testing and Materials, Philadelphia, p 125-139

Frausto Da Silva JJR, Williams RJP (1991) The biological chemistry of the element, the inorganic chemistry of life. Clarendon Press, Oxford

Friedman MH (1986) Principles and models of biological transport. Springer-Verlag, Berlin

Furness RW, Rainbow PS (1990) Heavy metals in the marine environment. CRC Press, Inc, Boca Raton, FL.

Gabriel KR (1978) A simple method of multiple comparisons of means. J Amer Statist Ass 73:724-729

Gachot B, Tau M, Morat L, Poujoel P (1991) Zinc uptake by proximal celis isolated from rabbit kidney: effects of cysteine and histidine. Pflügers Arch Eur J Phyisol 419: $583-587$

George SG, Coombs TL (1977) The effect of chelating agents on the uptake and accumulation of cadmium by the mussel Mytilus edulis. Mar Biol 39:261-268

Ginzburg G (1976) Calculation of all equilibrium concentrations in a system of competing complexation. Talanta 23 : $149-152$

Hawkins AD (1981) Aquarium systems. Academic Press, New York

Hering JG, Morel FMM (1990) The kinetics of trace metal complexalion: inplications fun ntetal teacivity hinatural waters. In: Stumm W (ed) Aquatic chemical kinetics. John Wiley, New York, p 145-171

Janssens HH, Scholz N (1979) Uptake and cellular distribu- 
tion of cadmium in Mytilus edulis. Mar Biol 55:133-141

Jenkins KD, Sanders BM (1986) Relationships between free cadmium ion activity in seawater, cadmium accumulation and subcellular distribution, and growth in polychaetes. Environ Health Perspect 65:205-210

Langston WJ (1990) Toxic effects of metals and the incidence of metal pollution in marine ecosystems. In: Furness RW, Rainbow PS (eds) Heavy metals in the marine environment. CRC Press, Inc, Boca Raton, FL, p 101-122

Martell AE, Smith RM (1974) Critical stability constants, Vol 1, Amino acids. Plenum Press, New York

Martell AE, Smith RM (1977) Critical stability constants. Vol 3, Other organic ligands. Plenum. Press, New York

Martell AE, Smith RM (1982) Critical stability constants, Vol 5. First supplement. Plenum Press, New York

Martin AW, Harrison FM, Huston MJ, Stewart DM (1958) The blood volume of some representative molluscs. J Exp Biol 35:260-279

Martin JM, Whitfield M (1981) The significance of the river input of chemical elements to the ocean. In: Wong CS Boyle E, Bruland KW, Burton JD, Goldberg ED (eds) Trace metals in sea water. Plenum Press, New York, p 265-296

viiilero $F J$ (1982) Use of models to determine ionlc interactions in natural waters. Thalassia Jugosl 18:253-291

Morton B (1992) The evolution and success of the heteromyarian form in the Mytiloida. In: Gosling $E$ (ed) The mussel Mytilus: ecology, physiology, genetics and culture.

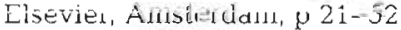

Motekaitis RJ, Martell AE (1987) Speciation of metals in the oceans. I. Inorganic complexes in. seawater, and influence of added chelating agents. Mar Chem 21:101-116

Palmer T (1991) Understanding enzymes. Ellis Horwood Ltd, Chichester

Pempkowiak J, Bancer B, Legezynska E, Kulinski W (1989) The accumulation and uptake of cadmium by four selected Baltic species in the presence of marine humic substances. In: Klekowski RZ, Styczynska-Jurewicz Falkowski L (ed) Proc 21st Eur Mar Biol Symp, Gdansk, Poland, 1988. Ossolineum, Gdansk, p 599-608

Pentreath RJ (1973) The accumulation from water of ${ }^{65} \mathrm{Zn}$, ${ }^{54} \mathrm{Mn},{ }^{58} \mathrm{Co}$ and ${ }^{59} \mathrm{Fe}$ by the mussel Mytilus edulis. I Mar Biol Ass UK 53:127-143

Phillips DJH (1980) Quantitative aquatic biological indicators. Applied Science Publishers Ltd, London

Rainbow PS, Malik I, O'Brien P (1993) Physicochemical and physiological effects on the uptake of dissolved zinc and

This article was submitted to the editor cadmium by the amphipod crustacean Orchestia gammarellus. Aquat Toxicol 25:15-30

Redpath KJ, Davenport J (1988) The effect of copper, zinc and cadmium on the pumping rate of Mytilus edulis L. Aquat Toxicol 13:217-226

Renfro WC, Fowler M, Heyraud M. La Rosa L (1975) Relative importance of food and water in long term zinc ${ }^{65}$ accumulation by marine biota. J Fish Res Bd Can 32:1139-1145

Simkiss K, Taylor MC (1989) Metal fluxes across the mem. branes of aquatic organisms. CRC Critical Rev Aquat Sci 1(1):173-188

Smith RM, Martell AE (1976) Critical stability constants, Vol 4, Inorganic ligands. Plenum Press, New York

Smith RM, Martell AE (1989) Critical stability constants, Vol 6. Second supplement. Plenum Press, New York

Sposito G, Traina SJ (1987) An ion-association model for highly saline, sodiumchlonde dominated waters. J Environ Qual 16(1):80-85

Turner DR (1984) Relationships between biological availability and chemical measurements. In: Sigel $\mathrm{H}$ (ed) Metal ions in biological systems. Marcel Dekker Inc, New York, p $137-165$

Turner DK, Whitfleld M, Dickson AG (1981) The equilibrium speciation of dissolved components in freshwater and seawater at $25^{\circ} \mathrm{C}$ and $1 \mathrm{~atm}$ pressure. Geochim Cosmochim Acta 45:855-881

Van den Berg CMG, Kramer JR (1979) Determination of complexing capacities of ligands in natural waters and conditional. stability constants of the copper complexes by means of manganese dioxide. Analyt Chim Acta 106: $113-120$

White SL, Rainbow PS (1985) On the metabolic requirements for copper and zinc in molluscs and crustaceans. Mar Environ Res 16:215-229

Widdows J (1985) Physiological procedures. In: Bayne BL. Brown DA, Burns K, Dixon DR, Ivanovici A, Livingstone DR, Lowe DM, Moore MN, Stebling ARD, Widdows J (ed) The effects of stress and pollution on marine animals. Praeger Press, New York, p 161-178

Zamuda CD, Sunda WG (1982) Bioavailability of dissolved copper to the American oyster, Crassostrea virginica: importance of chemical speciation. Mar Biol 66:77-82

Zurburg W, Kluytmans JH (1980) Organ specific changes in energy metabolism due to anaerobiosis in the sea mussel Mytilus edulis (L.). Comp Biochem Physiol Vol B 67 : $317-322$

Manuscript first received: September 4, 1995

Revised version accepted: February 15, 1996 